\title{
Effects of a single exposure to carbon disulphide on the rate of urea production and on plasma free fatty acid and glucose concentrations in the rat
}

\author{
V. J. CUNNINGHAM \\ Medical Research Council Toxicology Unit, Biochemical Mechanisms Section, \\ Medical Research Council Laboratories, Carshalton, Surrey, SM5 4EF
}

\begin{abstract}
Cunningham, V. J. (1975). British Journal of Industrial Medicine, 32, 140-146. Effects of a single exposure to carbon disulphide on the rate of urea production and on plasma free fatty acid and glucose concentrations in the rat. The concentration of plasma free fatty acids in rats was significantly increased after a short period of exposure to inhalation of carbon disulphide $(4 \mathrm{~h}, 2 \mathrm{mg} / \mathrm{l})$. In contrast, after a longer period of exposure $(15 \mathrm{~h}$ overnight, $2 \mathrm{mg} / \mathrm{l})$ the concentration of plasma free fatty acid was significantly decreased despite a small hypoglycaemia. At the same time plasma urea concentration was significantly higher in $\mathrm{CS}_{2}$ treated rats. The total esterified fatty acid content of plasma was lower after exposure, but there was no change in plasma glycerol. Following an intragastric water load, no differences were observed in urine flow rate nor in renal clearances of urea and inulin between control and treated rats. It is concluded that the rate of urea production is significantly increased during acute $\mathrm{CS}_{2}$-intoxication, and it is suggested that two factors contribute to this effect: first, an increased breakdown of proteins with which $\mathrm{CS}_{2}$ or its metabolic products have reacted; and secondly an increased rate of utilization of plasma glucose associated with increased gluconeogenesis from amino acid precursors. It is further suggested that the stress effects of $\mathrm{CS}_{2}$ dominate in the short term before being overcome by a diminished sympathetic response. When rats were exposed to $\mathrm{CS}_{2}$ overnight without free access to water, the great vessel haematocrit was significantly lower than in corresponding controls. This was shown to be accounted for by differences in plasma volume. No such difference was observed when rats had free access to water during exposure. These effects probably reflect differing rates of water loss under mildly dehydrating conditions, but a direct effect of $\mathrm{CS}_{\mathbf{2}}$ on the cardiovascular system is not excluded.
\end{abstract}

Carbon disulphide intoxication in man is associated with a wide variety of symptoms, ranging from headache and loss of appetite following acute exposure to an increased number of deaths due to heart disease with chronic exposure (Tiller, Schilling, and Morris, 1968; Hernberg et al, 1970; Brieger, 1961). Although the threshold limit value for $\mathrm{CS}_{2}$ is at present $60 \mu \mathrm{g} / \mathrm{l}$, acute exposure to levels of $\mathrm{CS}_{2}$ as high as $6 \mathrm{mg} / \mathrm{l}$ may occur if precautions are not taken at various stages in the manufacture of viscose rayon (Rosensteel, Shama, and Flesch, 1973). The work presented in this paper was undertaken as part of a study on the effects of acute intoxication in the rat.

During the course of this study an abnormal relationship between free fatty acid (FFA) and glucose concentrations in plasma after $\mathbf{C S}_{2}$ exposure was found and was associated with an increased 
concentration of plasma urea. It is the purpose of this paper to consider the possible relationship between these effects. In addition, routine measurements of haematocrits prompted a study of plasma volume after exposure to $\mathrm{CS}_{2}$. It was thought originally that the effects of $\mathrm{CS}_{2}$ on plasma volume and on plasma urea might be directly related in terms of an impairment of renal function. Evidence is presented that this is not the case. The changes in plasma volume appear to reflect a differing response to the mildly dehydrating conditions involved in the routine of exposure. The lines upon which further research will proceed are indicated, and suggestions for simple chemical observations on men acutely exposed to $\mathrm{CS}_{2}$ are put forward.

\section{Methods}

\section{Treatment of animals}

Male albino rats of the Porton strain were fed on MRC diet $41 \mathrm{~B}$ and weighed $200-250 \mathrm{~g}$ in the fed state. Food was removed at $09.30 \mathrm{~h}$ prior to rats being exposed either from $10.00-14.00 \mathrm{~h}$ or overnight $(18.30-09.30 \mathrm{~h})$ to $2 \mathrm{mg}$ carbon disulphide per litre of air in a vertical constant flow exposure chamber as described by Magos et al. (1970). Control rats were kept in similar chambers without $\mathrm{CS}_{2}$.

\section{Plasma sampling}

Rats were decapitated either within one hour of their removal from the chambers or at the end of the renal clearance experiments described below. In the former case, but not the latter, rats were anaesthetized with ether before decapitation. Blood was collected in polypropylene centrifuge tubes containing a small amount of powdered heparin. Plasma was separated by centrifugation at $10000 \mathrm{~g}$ for 10 minutes.

\section{Assay techniques}

Free fatty acids were extracted from samples $(1 \mathrm{ml})$ of plasma into heptane by the method of Dole and Meinertz (1960) as modified by Trout, Estes, and Friedberg (1960) and titrated as described by Cunningham (1973). Glucose (hexokinase method), urea, and glycerol concentrations in plasma were measured using assay kits supplied by the Boehringer Corporation (London) Ltd. For assay of glycerol, samples $(0.5 \mathrm{ml})$ of plasma were first deproteinized with an equal volume of trichloroacetic acid $(10 \% \mathrm{w} / \mathrm{v})$ and the latter was removed by ether extraction (Garland and Randle, 1962). Total esterified fatty acids were determined in samples $(0.3 \mathrm{ml})$ of plasma or in extracts of liver (see below) by the method of Stern and Shapiro (1953) using Tripalmitin (Sigma Chemical Co.) as a standard. Samples $(0.5 \mathrm{~g})$ of liver were excised and homogenized in ethanol/diethyl ether $(50 \mathrm{ml}, 3 / 1 \mathrm{v} / \mathrm{v})$. The extract was boiled and filtered and the residue was washed twice with hot ethanol/ether $(5 \mathrm{ml})$. Aliquots of the filtrate were taken for analysis of total esterified fatty acid.

\section{Plasma and red cell volumes}

${ }^{125}$ I-labelled human serum albumin and sodium chromate $\left({ }^{51} \mathrm{Cr}\right)$ solution were obtained from The Radiochemical
Centre, Amersham, Bucks. Donor rats received labelled albumin $(4 \mu \mathrm{Ci}$ in $0.2 \mathrm{ml}$ saline $(0.9 \% \mathrm{w} / \mathrm{v}))$ via a tail vein on the day preceding an experiment to screen for any component of the label that might be removed rapidly from the plasma (Dewey, 1959). Blood was collected into heparin by aortic cannulation under ether anaesthesia shortly before experiments, and ${ }^{125}$ I-labelled plasma was separated by centrifugation. ${ }^{51} \mathrm{Cr}$-tagged red cells were prepared essentially as described by Gray and Sterling (1950), as modified by Chaplin (1954) and Huggins, Smith, and Deavers (1966), and resuspended to a haematocrit of about $40 \%$ in ${ }^{125}$ I-labelled plasma. Rats received about $0.1 \mathrm{ml}$ doubly labelled blood via a tail vein from a weighed syringe, and after 15 minutes they were decapitated and blood was collected in heparin. Samples of collected blood and of injected material were analysed for ${ }^{125} \mathrm{I}$ and ${ }^{51} \mathrm{Cr}$ in a Panax Gamma 160 counter with suitable correction for overlap of ${ }^{51} \mathrm{Cr}$ counts in the ${ }^{125}$ I channel. Haematocrits were determined in duplicate and corrected for entrained plasma (Heath, 1973). Plasma and red cell volumes were calculated from the dilution of injected material after correction for the volume of the injected material and for loss of plasma label from the circulation (Dewey, 1959).

\section{Renal clearance experiments}

These experiments were based on the format of Dicker and Heller (1945). Within one hour of removal from the inhalation chambers, rats received tepid water intragastrically ( $5 \%$ body weight) and at the same time a subcutaneous injection of inulin $(5 \% \mathrm{w} / \mathrm{v})$ in physiological saline $(0.5 \mathrm{ml}$ per $100 \mathrm{~g}$ body wt)containing about $1 \mu \mathrm{Ci} / \mathrm{ml}$ (hydroxymethyl- ${ }^{14} \mathrm{C}$ )-inulin (Radiochemical Centre, Amersham, Bucks). One hour after the subcutaneous injection rats were made to urinate by gentle suprapubic pressure, this urine being discarded. Rats were then placed in individual metabolic cages which allowed collection of urine (Sharratt, 1970). After a measured period of about 30 minutes rats were made to urinate in the cages, blood samples then being collected after decapitation, and the concentrations of urea and total radioactivity were determined in plasma. Samples of urine were taken for assay of urea and radioactivity. The cages were rinsed with water, the total collected volume of urine plus rinses was recorded, and samples were taken for assay of total radioactivity excreted.

Samples of plasma $(0.1 \mathrm{ml})$, urine $(0.5 \mathrm{ml})$, and rinses $(1.0 \mathrm{ml})$ were added to $10 \mathrm{ml}$ of Instagel scintillation mixture (Packard Instrument Co. Inc.) and ${ }^{14} \mathrm{C}$-dpm counted using a Philips Liquid Scintillation Analyser PW 4510/01. Efficiency of counting was monitored with an external standard.

Clearance rates of urea $\left(\mathrm{C}_{\text {urea }}\right)$ and of inulin $\left(\mathrm{C}_{\mathrm{in}}\right)$ are expressed as millilitres plasma cleared per minute per $100 \mathrm{~g}$ body weight at the time of the experiment. The calculation of the rates from the above information assumes that the plasma concentrations of urea and of (hydroxymethyl- ${ }^{14} \mathrm{C}$ ) inulin were constant throughout the period of urine collection. This appeared to be the case for urea (see Results section) but was not established for (hydroxymethyl- ${ }^{14} \mathrm{C}$ ) inulin. The resulting overestimation of $C_{i n}$ is however likely to be small, would apply to both groups of rats considered, and would not affect the conclusions reached. 


\section{Results}

Free fatty acid and glucose concentrations in plasma after acute exposure of rats to $\mathbf{C S}_{2}$

In rats exposed to $\mathrm{CS}_{2}(2 \mathrm{mg} / \mathrm{l})$ from $10.00-14.00 \mathrm{~h}$, a significant increase in the concentration of FFA in plasma relative to that of controls was observed (Table 1). In contrast, after a longer period of exposure $(2 \mathrm{mg} / \mathrm{l}, 18.30-09.30 \mathrm{~h}$ overnight $)$ there was a significant decrease (Table 1). Rats were exposed overnight without access to food and with or without access to water. In each case a significantly lower plasma FFA concentration was observed in
CS $_{2}$-treated rats despite a small but significant hypoglycaemia (Table 2). Tarkowski and Cremer (1972) also report hypoglycaemia after 15 hours' exposure. Glycerol concentrations in plasma were measured as an indication of the rate of lipolysis in adipose tissue, but there were no significant differences in this parameter (Table 2).

The esterified fatty acid content of plasma was significantly lower in treated rats (Table 2), although there was no indication of fat accumulation in liver. The esterified fatty acid content of liver in eight $\mathrm{CS}_{2}$-treated rats was $133 \pm 8 \mu$ equiv/g wet weight (means \pm SEM) and in eight controls, $142 \pm 10$

\section{TABLE 1}

Free fatty Acid Concentrations in Plasma of Rats Acutely Exposed to CS 2

\begin{tabular}{|c|c|c|c|}
\hline \multirow{2}{*}{ Treatment } & \multicolumn{3}{|c|}{ Plasma FFA ( $\mu$ equiv/ml) } \\
\hline & \multirow{2}{*}{$\frac{\text { Control }}{0 \cdot 481 \underset{(24)}{ \pm} 0 \cdot 024}$} & \multicolumn{2}{|c|}{$C S_{2}$-treated } \\
\hline $\begin{array}{l}2 \mathrm{mg} \mathrm{CS} / 1 \\
10.00 \mathrm{~h}-14.00 \mathrm{~h} \\
\text { Rats in postabsorptive state }\end{array}$ & & $\begin{array}{c}0.600 \pm 0.038 \\
(24)\end{array}$ & $P<0.02$ \\
\hline $\begin{array}{l}2 \mathrm{mg} \mathrm{CS} / 1 \\
18.30 \mathrm{~h}-09.30 \mathrm{~h} \\
24 \mathrm{~h} \text { starved rats } \\
\text { NO ACCESS to water during exposure }\end{array}$ & $0.808 \underset{(37)}{ \pm} 0.026$ & $\begin{array}{c}0.654 \underset{(39)}{ \pm} 0.019 \\
\end{array}$ & $P<0.001$ \\
\hline $\begin{array}{l}2 \mathrm{mg} \mathrm{CS} / 1 \\
18.30 \mathrm{~h}-09.30 \mathrm{~h} \\
24 \mathrm{~h} \text { starved rats } \\
\text { FREE ACCESS to water }\end{array}$ & $0.821 \underset{(16)}{ \pm 0.027}$ & $\begin{array}{c}0.673 \pm 0.021 \\
(16)\end{array}$ & $P<0.001$ \\
\hline
\end{tabular}

Results are given as mean \pm SEM (number of rats). The significance of differences between means was assessed by Student's $t$ test.

TABLE 2

OVERNight EXPOSURE OF RATS To $\mathrm{CS}_{2}(2 \mathrm{mg} / \mathrm{l}, 15 \mathrm{~h})$

\begin{tabular}{|c|c|c|c|c|c|}
\hline \multirow[b]{2}{*}{ Condition } & \multicolumn{4}{|c|}{ Concentrations in plasma } & \multirow[b]{2}{*}{ Haematocrit } \\
\hline & Glucose $(m M)$ & Glycerol $(m M)$ & $\begin{array}{l}\text { Esterified fatty } \\
\text { acid }(\mu e q u i v / m l)\end{array}$ & Urea $(m M)$ & \\
\hline $\begin{array}{l}\text { Without free access to } \\
\text { water during exposur } \\
\text { Control } \\
\mathrm{CS}_{2} \text { treated } \\
\text { P }\end{array}$ & $\begin{aligned} 6.97 & \pm 0.17(24) \\
5.83 & \pm 0.18(24) \\
& <0.001\end{aligned}$ & $\begin{array}{c}0.166 \pm 0.010(16) \\
0.169 \pm 0.011(16) \\
\text { NS }\end{array}$ & $\begin{aligned} 5 \cdot 72 & \pm 0 \cdot 17(28) \\
4 \cdot 30 & \pm 0 \cdot 10(30) \\
& <0.001\end{aligned}$ & $\begin{array}{c}8.72 \pm 0.49(6) \\
11.2 \pm 0.8 \text { (6) } \\
<0.05\end{array}$ & $\begin{array}{c}46.5 \pm 0.4(23) \\
41.9 \pm 0.3(23) \\
<0.001\end{array}$ \\
\hline $\begin{array}{l}\text { With free access to } \\
\text { water during exposur } \\
\text { Control } \\
\mathrm{CS}_{\mathbf{2}} \text { treated } \\
\text { P }\end{array}$ & $\begin{aligned} 7.00 & \pm 0.18(16) \\
6.26 & \pm 0.18(16) \\
& <0.01\end{aligned}$ & $\begin{array}{c}0.207 \pm 0.008(16) \\
0.187 \pm 0.007(16) \\
\text { NS }\end{array}$ & $\begin{aligned} 5.76 & \pm 0.18(15) \\
4.07 & \pm 0.23(15) \\
& <0.001\end{aligned}$ & $\begin{array}{c}5.63 \pm 0.20(6) \\
9.11 \pm 0.36(6) \\
<0.001\end{array}$ & $\begin{array}{l}- \\
-\end{array}$ \\
\hline
\end{tabular}

All rats had been starved for $24 \mathrm{~h}$. Results are expressed as mean $\pm \mathrm{SEM}$ (number of rats). The significance of differences between means was assessed by Student's $t$ test. 
$\mu$ equiv/g wet weight. In addition, it was observed that $\mathrm{CS}_{2}$-treated rats had significantly higher plasma urea concentrations, the increase relative to controls being greater in rats given free access to water (Table 2).

\section{Plasma and red cell volumes}

Lower haematocrit values were consistently observed in rats exposed to $\mathrm{CS}_{2}$ when there was no free access to water during exposuie (Table 2). Because changes in plasma volume might affect the concentration of plasma constituents, and because this effect might reflect a direct action of $\mathrm{CS}_{2}$ on the cardiovascular system, an analysis of the factors affecting the observed haematocrit was carried out after simultaneous intravenous injection of 125[-labelled albumin and ${ }^{51} \mathrm{Cr}$-tagged red cells (Table 3 ).

When control rats not allowed access to water are compared with control rats allowed access to water, a small but significant decrease in plasma volume, expressed as \% body weight at the time of determination, is seen to account for an increased great vessel haematocrit. This effect is consistent with reports that the plasma volume in rats reduces proportionately more than body weight under dehydrating conditions (Kutscher, 1968; Horowitz and Borut, 1970; Mogharabi and Haines, 1973). No significant differences were observed in total red cell volume or in $F_{\text {cells }}$ (ihe ratio between the true whole blood haematocrit and the observed great vessel haematocrit (Gregersen and Rawson, 1959)). Thus the observed changes in haematocrit are attributable solely to changes in plasma volume.

In contrast, no such effect on plasma volume was seen in the case of $\mathrm{CS}_{2}$-treated rats (Table 3) and there were also no changes in total red cell volume or in $F_{\text {cells. }}$ The difference in haematocrit between control and $\mathrm{CS}_{2}$-treated rats when there was no free access to water (Table 2) may therefore stem from the differing response of the rats to conditions of mild dehydration. Either the $\mathrm{CS}_{2}$-treated rats did not dehydrate to the same extent as control rats or they had an abnormal water distribution.

\section{Renal function tests}

Two observations prompted the renal function tests

TABLE 3

Plasma and Red Cell Volumes in Rats exposed to $\mathrm{CS}_{2}(2 \mathrm{mg} / \mathrm{l})$ Overnight with and without Free ACCESS TO WATER

\begin{tabular}{|c|c|c|c|c|}
\hline & & Free access to water & No access to water & \\
\hline Control & $\begin{array}{l}\text { Plasma volume } \\
\text { Red cell volume } \\
\text { Haematocrit } \\
\text { F cells }\end{array}$ & $\begin{aligned} 4 \cdot 37 & \pm 0.08 \\
2 \cdot 31 & \pm 0.04 \\
42 \cdot 6 & \pm 0.6 \\
0.814 & \pm 0.008\end{aligned}$ & $\begin{array}{cl}4.10 & \pm 0.08 \quad(6) \\
2.37 & \pm 0.04 \\
44.4 & \pm 0.5 \\
0.826 & \pm 0.008\end{array}$ & $\begin{array}{l}\mathrm{P}<0.05 \\
\mathrm{NS} \\
\mathrm{P}<0.05 \\
\mathrm{NS}\end{array}$ \\
\hline $\mathrm{CS}_{\mathbf{2}}$-treated & $\begin{array}{l}\text { Plasma volume } \\
\text { Red cell volume } \\
\text { Haematocrit } \\
\text { F cells }\end{array}$ & $\begin{aligned} 4.46 & \pm 0.7 \\
2.29 & \pm 0.05 \\
42.2 & \pm 0.4 \\
0.827 & \pm 0.013\end{aligned}$ & $\begin{aligned} 4.38 & \pm 0.06 \quad(7) \\
2 \cdot 30 & \pm 0.03 \\
\mathbf{4 2 \cdot 3} & \pm 0.3 \\
0.839 & \pm 0.010\end{aligned}$ & $\begin{array}{l}\text { NS } \\
\text { NS } \\
\text { NS } \\
\text { NS }\end{array}$ \\
\hline
\end{tabular}

Volumes are expressed as $\mathrm{ml} / 100 \mathrm{~g}$ body weight at time of determination. Results are expressed as mean \pm SEM with number of rats in parentheses.

TABLE 4

InULin ANd URea Clearances in CS 2 TREATEd ANd CONTROL RATS

\begin{tabular}{|c|c|c|c|c|c|}
\hline & $\begin{array}{c}\text { Plasma urea } \\
\text { concentration } \\
(m M)\end{array}$ & $\begin{array}{c}\text { Rate of urea } \\
\text { excretion } \\
(\mu \text { moles } / \text { min } / 100 \mathrm{~g} \\
\text { body } w \text { t) }\end{array}$ & $C_{u r e a}$ & $\begin{array}{c}C_{i n} \\
(\operatorname{ml} / \min / 100 \mathrm{~g} \text { body wt })\end{array}$ & Urine flow rate \\
\hline $\begin{array}{l}\mathrm{CS}_{2} \\
\text { Control }\end{array}$ & $\begin{array}{c}10.13 \pm 0.46 \\
6.83 \pm 0.32 \\
P<0.001\end{array}$ & $\begin{array}{l}4.14 \pm 0.41 \\
2.76 \pm 0.36 \\
P<0.05\end{array}$ & $\begin{array}{c}0.409 \pm 0.036 \\
0.404 \pm 0.049 \\
\text { NS }\end{array}$ & $\begin{array}{c}0.851 \pm 0.052 \\
0.909 \pm 0.060 \\
\text { NS }\end{array}$ & $\begin{array}{c}0.052 \pm 0.006 \\
0.044 \pm 0.004 \\
\text { NS }\end{array}$ \\
\hline
\end{tabular}

All rats were starved for $24 \mathrm{~h}$ but had free access to water during exposure. After exposure in the presence or absence of $\mathrm{CS}_{2}(2 \mathrm{mg} / 1,15 \mathrm{~h})$ rats received a subcutaneous injection of labelled inulin and an intragastric water load. After $1 \mathrm{~h}$, urine was collected for a period of about $30 \mathrm{~min}$. Inulin clearance and urine flow rate were measured in nine rats in each group, and urea clearance in six of these nine rats. 
(Table 4): first, a significantly higher plasma urea concentration in treated rats (Table 2), and, second, a possible change in fluid balance. In rats exposed to $\mathrm{CS}_{2}(2 \mathrm{mg} / \mathrm{l})$ overnight with free access to water, and in corresponding controls, inulin clearance and urine flow rate were the same after an intragastric water load (Table 4). The difference in plasma urea concentration between the two groups at the end of the clearance experiments (Table 4) was similar to that observed in separate experiments immediately after exposure (Table 2), and plasma urea concentrations were therefore assumed to be constant while renal clearance was measured. This difference in concentration between groups was accompanied by a corresponding difference in the rate of urea excretion, i.e., plasma urea clearance was the same in both groups (Table 4).

\section{Discussion}

The renal function tests carried out on rats following acute $\mathrm{CS}_{2}$-intoxication indicate that the raised plasma urea is not due to any renal malfunction leading to a decreased elimination of urea but to an increased rate of urea production in the animal. Although the possibility of a reversible change during exposure is not excluded, it is clear that there is no direct relationship in terms of renal function between the raised plasma urea and the effects of $\mathrm{CS}_{2}$ on plasma volume. After a period of overnight exposure to $\mathrm{CS}_{2}$ the rats showed signs of sedation, and it is possible that the evaporative loss of water may have been affected by differences in physical activity and pulmonary ventilation during exposure. No significant differences in weight loss during exposure were observed (results not shown), but it is emphasized that the conditions of dehydration were mild and that plasma volume in control rats decreased proportionately more than body weight. It is therefore not possible to distinguish, on the basis of these results, an effect of $\mathrm{CS}_{2}$ on water loss from an effect on fluid distribution in the animal.

The two most obvious changes in concentration of rat plasma constituents after $\mathbf{C S}_{2}$ intoxication were those of urea and esterified fatty acids. These concentrations are easily determined and may be of some use in the assessment of the degree of acute $\mathrm{CS}_{2}$-intoxication in man, although the dependence of both concentrations on a variety of factors, notably diet, would reduce their diagnostic usefulness. On inhalation $\mathrm{CS}_{2}$ is taken up by all tissues in the body where it is found in both free and bound forms (Brieger, 1967). It may react directly with a variety of amino acid side chains (Vašák and Kopecký, 1967) and has, for example, been shown to react with plasma albumin (Brieger, 1967). The increased rate of urea production may therefore reflect, in part, the breakdown of such amino acids and proteins with which $\mathrm{CS}_{2}$ or its metabolic products have reacted. A further possible contributory cause of the increased rate of urea production, namely an increased demand for glucose in the whole animal, is discussed later.

If the fall in plasma concentration of esterified fatty acid after $\mathrm{CS}_{2}$ is due to decreased secretion of lipoprotein by the liver, then two factors may be involved: (a) a lower plasma-free fatty acid concentration leading to reduced uptake of free fatty acid by the liver, and $(b)$ decreased synthesis of the protein moiety of lipoproteins. This latter factor may be related to an increased breakdown of amino acids or to a transient inhibition of protein synthesis in the liver of $\mathrm{CS}_{2}$-treated rats (Bond and de Matteis, 1969). However, no accumulation of esterified fatty acid in total liver samples was observed in the present work, and in the absence of more detailed study of plasma triglyceride turnover after acute $\mathrm{CS}_{2}$-intoxication no further comment can be made.

The rise in plasma FFA concentration which occurred after four hours' exposure is in marked contrast to the fall which took place after 15 hours' exposure, despite an associated hypoglycaemia. Preliminary investigations indicate no difference in the fractional turnover rate of plasma FFA after $\mathrm{CS}_{2}$-intoxication (Cunningham, unpublished observations), and it is therefore assumed that the fall in plasma FFA concentration is due to a decreased output of FFA from adipose tissue. The absence of any significant differences in plasma glycerol concentrations suggests that an increased re-esterification of FFA in adipose tissue rather than decreased lipolysis was occurring. Although the hypoglycaemia is small in itself, failure of the rat to respond by an expected increased output of FFA from adipose tissue is significant. Because of the role of catecholamines in the release of FFA from adipose tissue and in the supply of plasma-borne substrates to the tissues, such an abnormal response to a lowered glucose concentration is consistent with the report of Magos and Jarvis (1970) that successive exposures of rats at the level used here $(2 \mathrm{mg} / \mathrm{l})$ results in a progressive inhibition of catecholamine synthesis. Magos, Jarvis, and Butler (1974) have put forward an hypothesis relating symptoms of $\mathrm{CS}_{2}$ intoxication to a disturbed catecholamine metabolism. However, it is emphasized that after a short exposure of four hours an increased plasma FFA concentration was observed. It is possible that during such an exposure a non-specific stressful effect dominates before being overcome by progressive inhibition of the sympathetic response.

What light do the changes observed in these experiments throw on the mode of action of $\mathrm{CS}_{2}$ ? If the changes observed in plasma substrate concentrations may be attributed principally to a single central effect, two observations in the present work 
suggest that the measurement of the turnover rate of plasma glucose in the whole animal may be of importance. In the normal rat, the fractional turnover rate of plasma glucose correlates positively with its concentration (Heath and Corney, 1973), such that a fall in the latter is associated with a proportionately greater fall in the absolute rate of its utilization. That this relationship might not hold when $\mathrm{CS}_{2}$ treated rats are compared with corresponding controls is consistent with $(a)$ a lower output of FFA from adipose tissue, probably due to an increased rate of re-esterification despite hypoglycaemia, and (b) the higher rate of urea production if this were consequent upon an increased rate of gluconeogenesis from amino acid precursors. In addition, Kürzinger and Freundt (1969) report diminution of liver glycogen in rats exposed to $\mathrm{CS}_{2}$, suggesting an increased demand for glucose. While the observed changes might also reflect a lower overall metabolic rate in the $\mathrm{CS}_{2}$-treated rat, the above hypothesis can be tested by the direct determination of the fractional turnover rate of plasma glucose which will form the basis for future work.

I am greatly indebted to Mrs. Linda Hay and Mrs. Christine George for skilled technical assistance during this work.

\section{References}

Bond, E. J. and de Matteis, F. (1969). Biochemical changes in rat liver after administration of carbon disulphide, with particular reference to microsomal changes. Biochemical Pharmacology, 18, 2531-2549.

Brieger, H. (1961). Chronic carbon disulfide poisoning. Journal of Occupational Medicine, 3, 302-308.

(1967). Carbon disulphide in the living organism. In Toxicology of Carbon Disulphide, an International Symposium, pp. 27-31, edited by $\mathbf{H}$. Brieger and J. Teisinger. Excerpta Medica Foundation, Amsterdam.

Chaplin, H., Jr. (1954). Precision of red cell volume measurement using ${ }^{32} \mathrm{P}$-labelled cells. Journal of Physiology, 123, 22-31.

Cunningham, V. J. (1973). The irreversible disposal rate of free fatty acids in the plasma of fed and starved rats. Biochemical Journal, 136, 545-550.

Dewey, W. C. (1959). Vascular-extravascular exchange of $I^{131}$ plasma proteins in the rat. American Journal of Physiology, 197, 423-431.

Dicker, S. E. and Heller, H. (1945). The mechanism of water diuresis in normal rats and rabbits as analysed by inufin and diodone clearances. Journal of Physiology, 103, 449-460.

Dole, V. P. and Meinertz, H. (1960). Microdetermination of long-chain fatty acids in plasma and tissues. Journal of Biological Chemistry, 235, 2595-2599.

Garland, P. B. and Randle, P. J. (1962). A rapid enzymatic assay for glycerol. Nature, 196, 987-988.

Gray, S. J. and Sterling, K. (1950). Determination of circulating red cell volume by radioactive chromium. Science, 112, 179-180.
Gregersen, M. I. and Rawson, R. A. (1959). Blood volume. Physiological Reviews, 39, 307-342.

Heath, D. F. (1973). The effect of scald injury upon the distribution of glucose between red cells and plasma and upon the turnover of glucose in red cells in the rat. British Journal of Experimental Pathology, 54, 359-360.

_- , and Corney, P. L. (1973). The effects of starvation, environmental temperature and injury on the rate of disposal of glucose by the rat. Biochemical Journal, 136, 519-530.

Hernberg, S., Partanen, T., Nordman, C-H., and Sumari, P. (1970). Coronary heart disease among workers exposed to carbon disulphide. British Journal of Industrial Medicine, 27, 313-325.

Horowitz, M. and Borut, A. (1970). Effect of acute dehydration on body fluid compartments in three rodent species. Rattus norvegicus, Acomys cahirinus and Meriones crassus. Comparative Biochemistry and Physiology, 35, 283-290.

Huggins, R. A., Smith, E. L., and Deavers, S. (1966). $\mathrm{Cr}^{51}$-tagged red cell equilibration in dogs. American Journal of Physiology, 211, 283-287.

Kürzinger, R. and Freundt, K. J. (1969). Changes in hepatic functions following exposure to low carbon disulphide levels. Naunyn-Schmiedeberg's Archiv für experimentelle Pathologie und Pharmakologie, 264, 261.

Kutscher, C. (1968). Plasma volume change during waterdeprivation in gerbils, hamsters, guinea-pigs and rats. Comparative Biochemistry and Physiology, 25, 929-936.

Magos, L., Emery, R C., Lock, R. D., and Firmager, B. G. (1970). A vertical-type constant flow inhalation chamber for rats. Laboratory Practice, 19, 725-727.

- and Jarvis, J. A. E. (1970). The effects of carbon disulphide exposure on brain catecholamines in rats. British Journal of Pharmacology, 29, 26-33.

- , and Butler, W. H. (1974). Experimental approach for the study of cardiovascular toxicity of $\mathrm{CS}_{2}$. In Proceedings of the European Society for the Study of Drug Toxicity, Vol. 15. Excerpta Medica, Amsterdam.

Mogharabi, F. and Haines, H. (1973). Dehydration and body fluid regulation in the thirteen-lined ground squirrel and laboratory rat. American Journal of Physiology, 224, 1218-1222.

Rosensteel, R. E., Shama, S. K., and Flesch, J. P. (1973). Health Hazard Evaluation Determination Report 72-21-91. U.S. Department of Health, Education and Welfare. National Institute for Occupational Safety and Health. Cincinnati, Ohio 45201.

Sharratt, M. (1970). Renal function tests in laboratery animals. In Metabolic Aspects of Food Safety, edited by F. J. C. Roe, pp. 119-171. Scientific Publications, Oxford and Edinburgh.

Stern, J. and Shapiro, B. (1953). A rapid and simple method for the determination of esterified fatty acids and for total fatty acids in blood. Journal of Clinical Pathology, 6, 158-160.

Tarkowski, S. and Cremer, J. E. (1972). Metabolism of glucose and free amino acids in brain, studied with ${ }^{14} \mathrm{C}$-labelled glucose and butyrate in rats intoxicated with carbon disulphide. Journal of Neurochemistry, 19, 2631-2640.

Tiller, J. R., Schilling, R. S. F., and Morris, J. N. (1968), 
Occupational toxic factor in mortality from coronary heart disease. British Medical Journal, 4, 407-411.

Trout, D. L., Estes, E. H., and Friedberg, S. J. (1960). Titration of free fatty acids of plasma: a study of current methods and a new modification. Journal of Lipid Research, 1, 199-201.

Vašák, V. and Kopecký, J. (1967). On the role of pyridoxamine in the mechanism of the toxic action of carbon disulphide. In Toxicology of Carbon Disulphide, an International Symposium, edited by $\mathrm{H}$. Brieger and J. Teisinger, pp. 35-41. Excerpta Medica Foundation, Amsterdam.

Received for publication 17 June 1974

Accepted for publication 27 September 1974

\section{The February (1975) Issue}

A follow-up study of coronary heart disease in viscose rayon workers exposed to carbon disulphide M. TOLONEN, S. Hernberg, M. Nurminen, and K. Tittola

Thenar muscle blood flow and bone mineral in the forearms of lumberjacks P. KARJALAinen, E. M. Alhava, AND J. VAltola

Prevalence of asbestos bodies in a necropsy series in East London: association with disease, occupation, and domiciliary address I. Doniach, K. V. Swettenham, and M. K. S. HathorN

Neurotoxicity of acrylamide and its analogues and effects of these analogues and other agents on acrylamide neuropathy PHILIPPA M. EDWARDS

Effect of asbestos on lipid peroxidation in the red cells Silvia GabOR AND ZoE ANCA

Effect of repeated exposure to aniline, nitrobenzene, and benzene on liver microsomal metabolism in the rat Justyna M. WišnieWsKa-KnYPl, Janina K. JABŁonSKA, AND Jerzy K. PiotrowsKi

Toxic effects of 2,3,7,8 tetrachlorodibenzo 1,4 dioxin in laboratory workers R. M. OLIVER

Haemolytic episode in G6 PD deficient workers exposed to TNT L. S. DJERASSI AND L. VITANY

Occupational absorption of tellurium: a report of two cases E. S. BLACKADDER AND W. G. MANDERSON

A cohort study of bronchial carcinomas in workers producing chromate pigments S. LANGÅRD AND T. NORSETH

A clinical and radiographic study of coir workers C. G. URAGODA

Long-term effects on the health of men engaged in the manufacture of tolylene di-isocyanate W. G. F. AdAMs

Book reviews

Information section

A number of copies are still available and may be obtained from the Publishing Manager, British Medical Association, Tavistock Square, London WC1H 9JR, price £2.50; U.S.A. \$7.50). 